\title{
A produção do espaço urbano em cidades médias paulistas: o caso de São João da Boa Vista (SP)
}

\author{
Claudete C. Vitte (PQ), Charles S. Tabarin (IC).
}

\section{Resumo}

A pesquisa teve como objetivo promover uma contribuição sobre a produção do espaço urbano em cidades médias, a partir do estudo de caso de São João da Boa Vista (SP). A metodologia do trabalho abrangeu a revisão bibliográfica, análise de dados do Censo IBGE de 2010, estudo de documentos públicos e leis, como o Plano Diretor e, elaboração de mapas. Com isso, constatou-se uma forte intervenção de agentes produtores do espaço urbano na expansão segregada da cidade, por meio de ações estatais, principalmente nas novas periferias, com o Programa Minha Casa, Minha Vida e, da iniciativa privada, com a execução de condomínios horizontais fechados e loteamentos diversos.

Palavras Chave: Geografia Urbana, Produção do Espaço Urbano, São João da Boa Vista.

\section{Introdução}

O objetivo da pesquisa foi promover uma contribuição relativa à produção do espaço urbano em cidades médias, com base no estudo de caso de São João da Boa Vista (SP). Além da compreensão da espacialização de fenômenos, como a segregação espacial, por meio da ação de agentes sociais, como o Estado e o mercado. As cidades do interior paulista, nos últimos anos, passaram por intenso crescimento econômico e, consequentemente, por crescimento urbano. São João da Boa Vista se incluí nessa tendência e sua formação espacial ocorre a partir da ação de diversos agentes sociais, desde os fundadores históricos, até a regulação das ações estatais e a iniciativa privada, incluindo os residentes de menor poder aquisitivo.

\section{Resultados e Discussão}

A metodologia utilizada no projeto envolveu a revisão bibliográfica sobre produção do espaço urbano; caracterização socioeconômica e histórica do município, a partir de dados do Censo IBGE de 2010 e observações de campo; verificação do papel do Estado como regulador e gestor, recorrendo à análise de documentos públicos, como o Plano Diretor e, a elaboração de mapas através do uso do software ArcGis 10.

Segundo Côrrea (2013) ${ }^{1}$, a espacialidade da segregação residencial manifesta-se pela concentração de grupos homogêneos em determinadas áreas, viabilizando sua reprodução. Nesse contexto, a ação estatal, em consonância com os interesses privados, teve papel fundamental na segregação sócio espacial, especialmente residencial, em São João da Boa Vista.

O Estado regulamenta a produção do espaço urbano a partir do Plano Diretor, implantado no ano de 2006 no município, com base em decisões locacionais, públicas ou privadas, em áreas como transporte, zoneamento, localização dos bens públicos e de moradias, segundo Silva $(2012)^{2}$. Também produz o espaço com o estabelecimento de programas sociais, como o Minha Casa, Minha Vida, com a construção de domicílios para populações de menor renda, localizadas nas periferias distantes do centro da cidade.

Já com a análise de mapas elaborados com o software ArcGis 10 e trabalhos de campo realizados, pode-se confirmar a organização segregada por renda, na qual observou-se a concentração de domicílios de alta renda nas regiões centrais e leste do município, e de média e baixa renda no restante da cidade.

\section{Conclusões}

A produção do espaço urbano em São João da Boa Vista ocorre com a ação de diferentes agentes, a partir do planejamento estatal em consenso com interesses privados, promovendo uma expansão baseada na segregação sócio espacial de grupos homogêneos, dispondo de infraestruturas desiguais.

\section{Agradecimentos}

Agradecemos ao apoio do Conselho Nacional de Desenvolvimento Científico e Tecnológico (CNPq), orientadora, família e amigos.

\footnotetext{
${ }^{1}$ CORREA, R.L. Segregação residencial: classes sociais e espaço urbano. In Vasconcelos P.A. (et al). (Orgs). A cidade Contemporânea: Segregação Espacial. - São Paulo: Contexto, 2013 ${ }^{2}$ SILVA, Érica T. da. Estrutura Urbana e Mobilidade Espacial nas metrópoles. Tese apresentada ao Curso de Doutorado do Programa de Pós-Graduação em Planejamento Urbano e Regional da Universidade Federal do Rio de Janeiro - UFRJ. Rio de Janeiro, 2012.
} 